\title{
Rhesus Negative Pregnancy: Prevalence and Foetomaternal Outcomes in a Tertiary Hospital, South-South Nigeria
}

\author{
Dennis Oju Allagoa ${ }^{1}$, Peter Chibuzor Oriji ${ }^{1 *}$, Datonye Christopher Briggs ${ }^{2}$, Chima Ikoro ${ }^{1}$, Chidozie \\ Emmanuel Unachukwu ${ }^{3}$, Akaninyene Eseme Ubom ${ }^{4}$, Gordon Atemie ${ }^{1}$ and Barbara Eneni ${ }^{1}$ \\ ${ }^{1}$ Dept. of Obstetrics and Gynaecology, Federal Medical Centre, Yenagoa, Bayelsa State, Nigeria; ${ }^{2}$ Dept. of Paediatrics, \\ Rivers State University Teaching Hospital, Port Harcourt, Rivers State, Nigeria; ${ }^{3}$ Dept. of Obstetrics and Gynaecology, Niger \\ Delta University Teaching Hospital, Okolobiri, Bayelsa State, Nigeria; ${ }^{4}$ Dept. of Obstetrics, Gynaecology and Perinatology, \\ Obafemi Awolowo University Teaching Hospitals Complex, Ile-Ife, Osun State, Nigeria. \\ *Correspondence: chibuzor54@gmail.com (Dr. Peter Chibuzor Oriji, Dept. of Obstetrics and Gynaecology, Federal Medical \\ Centre, Yenagoa, Bayelsa State, Nigeria).
}

\section{ABSTRACT}

Rhesus incompatibility can pose a problem in pregnancy and cause obstetric failure in a handful of women. The Rhesus factor is a red blood cell surface antigen; and there are many antigen subtypes that make up the Rhesus blood group systems, of which the most commonly involved and most immunogenically associated with Rhesus isoimmunisation is the D antigen. The objective of this study is to determine the prevalence of Rhesus negativity and the foetomaternal outcomes at the Federal Medical Centre, Yenagoa, Bayelsa State, Nigeria. This was a 5-year retrospective study conducted between $1^{\text {st }}$ January, 2016 and $31^{\text {st }}$ December, 2020 at our Obstetric Unit. Data were retrieved, entered into a pre-designed preformed and analyzed using SPSS version 25.0. Results were presented as mean and standard deviation for continuous variables and frequencies or percentages for categorical variables. Of the 4,571 pregnant women, 104 were Rhesus negative, giving a rate of 2.27\%. The most common blood group among the women (53.8\%) and their partners (84.6\%) was the O blood group. Only $2(1.9 \%)$ women were sensitised. Out of the 104 Rhesus negative women, 81 were unsensitised (77.9\%) and received anti-D immunoglobulin. Majority of the babies had a good outcome, though 19 (18.2\%) of them were admitted into the special care baby unit for various conditions. The incidence of Rhesus negative pregnancy in our study was $2.27 \%$, and $1.9 \%$ of the women were sensitised. Prompt administration of anti-D immunoglobulin after sensitising events and post-delivery is key in the prevention of Rhesus isoimmunisation.

Keywords: Rhesus, Pregnancy, Antigen, Isoimmunisation, Foetomaternal, Unsensitised, and Sensitised.

\section{INTRODUCTION:}

The Rhesus system was first described by Landsteiner and Weiner in 1940 (Schwarz and Dorner, 2003). Rhesus incompatibility can pose a problem in pregnancy and cause obstetric failure in a handful of women (Adeyemi and Bello-Ajao, 2016). The Rhesus factor is a red blood cell surface antigen. There are many antigen subtypes that make up the Rhesus blood group UniversePG I www.universepg.com systems. These include the D, d, C, c, E, e, G antigen subtypes, of which the most commonly involved and most immunogenically associated in Rhesus isoimmunisation is the D antigen (Moise and Kennedy, 2021; Erhabor and Charles, 2010). Rhesus isoimmunisation is a condition that occurs when a woman with Rhesus negative blood type is exposed to Rhesus positive blood cells, leading to the development of Rhesus 
antibodies. This isoimmunisation can occur when a Rhesus negative pregnant mother is exposed to Rhesus positive foetal red blood cells due to foetomaternal haemorrhage during the course of pregnancy or when a Rhesus negative woman is trans-fused with Rhesus positive blood (Adeyemi and Bello-Ajao, 2016; Erhabor and Charles, 2010; Salem and Singer, 2017). Basque populations have the highest incidence of $\mathrm{Rh}$ negativity (30 - 35\%) (Roman, 2013). Caucasian populations in general have a higher incidence than other ethnic groups (15-16\%) (Roman, 2013). Blacks in the United States have a rate of $8 \%$, African blacks $4 \%$, Indoeurasians 2\% and North American Indians 1\% (Roman, 2013). Gene-rally, the reported incidence from various studies in Nigeria range between 2.5 9.5\% (Onwuhafua and Adze, 2005; Idowu et al., 2003). When a Rhesus-D negative woman carries a Rhesus-D positive foetus, and foetal red blood cells pass into the mother's circulation through Transplacental haemorrhage, maternal antibodies to the Rhesus antigen may develop and cross the placenta, causing haemolysis of foetal blood cells. The haemolytic disease of the foetus and newborn with the resultant anaemia can result in serious foetal/neonatal morbidity or mortality.

Isoimmunisation with its consequences is however preventable with the timely administration of the anti D immunoglobulin to unsensitised Rhesus negative mothers as well as prevention of sensitisation. Approximately $16 \%$ of Rhesus-D negative women became sensitised after two deliveries of Rhesus-D positive ABO - compatible infants, before the development of anti - D immunoglobulin (Roman, 2013). This rate was reported to have significantly reduced to $1 \%-2 \%$ following regular administration of a single dose of anti - D immunoglobulin within 72 hours of delivery, and even reduced further to $0.1 \%-0.3 \%$ with the addition of routine antenatal administration in the third trimester (Moise and Ken-nedy, 2021). A high risk of obstetric sensitisation in Rhesus negative women still exist in the developing countries due to high prevalence of unbooked antenatal cases and paucity of screening facilities at antenatal clinics (Adeyemi and Bello-Ajao, 2016; Erhabor and Charles, 2010). The high cost of the basic prophylactic anti-D immunoglobulin injection also hinders achieving a high level of prevention, as seen in the developed countries (Adeyemi and Bello-Ajao, 2016; Erhabor and Charles, 2010). Previous sensitisation is excluded by a negative indirect Coomb's test. The indirect Coomb's test is repeated at 28 and 34 weeks of gestation because of the risk of antenatal sensitization in the third trimester due to occult foetomaternal haemorrhage (Roman, 2013). This is particularly important for the regions of the world with high incidence of Rhesus negativity.

Anti-D immunoglobulin should also be administered during pregnancy when there is the possibility of small amount of blood crossing the placenta into the maternal circulation such as during miscarriage, antepartum haemorrhage, external cephalic version and other invasive procedures like cordocentesis, amniocentesis and chorionic villus sampling. Routine antenatal administration to unsensitised women at 28 and 34 weeks of gestation has been recommended due to the risk of occult antepartum foetomaternal haemorrhage (National Institute for Health and Care Excellence, 2008). This practice is however challenged in our environment by the relative high cost of the anti-D immunoglobulin. In addition, the incidence of Rhesus negativity and sensitisation is low in our sub-region. After delivery of the baby, umbilical cord blood is tested to determine the baby's blood group before administration of $300 \mu \mathrm{g}$ of anti-D immunoglobulin. Anti-D immunoglobulin is given to Rhesus-D negative mothers within 72 hours of delivery of a Rhesus-D positive baby. It is not given if the baby's blood group is $\mathrm{O}$ Rhesus-D negative. The quantity of foetomaternal haemorrhage is increased during Caesarean section and manual removal of placenta and a higher dose of antiD immunoglobulin may be required in these circumstances. The Kleihauer Betke's acid elution test or flow cytometry may be used to quantify foetomaternal haemorrhage where such facilities are available. This helps to identify women who may need additional doses of anti-D immunoglobulin because of a large volume of foetomaternal haemorrhage. Rhesus negative women should be counselled on the need for early booking, adequate antenatal evaluation and monitoring as well as effective anti-D immunoprophylaxis. All pregnant women, especially primigravidae should have their Rhesus blood group determined at the booking clinic in view of the significance of Rhesus isoimmuni- 
sation. Anti-D immunoglobulin should also be made available and affordable for immunoprophylaxis for unsensitised women. The objective of this retrospective survey was to determine the prevalence of Rhesus negativity and the foetomaternal outcomes at Federal Medical Centre, Yenagoa, Bayelsa State, Nigeria, over a 5-year period.

\section{MATERIALS AND METHODS:}

We conducted a 5-year retrospective review spanning from $1^{\text {st }}$ January, 2016 to $31^{\text {st }}$ December, 2020 in the Obstetric Unit of the Federal Medical Centre, Yenagoa, Bayelsa State, Southern Nigeria. All women who were Rhesus negative and managed in our Centre within period under review were included in this study; all other patients with diagnosis other than being Rhesus negative were excluded. The ABO blood group and Rhesus factor are part of the routine investigations requested at the antenatal booking visit or in the course of management of patients in our Centre. Indirect Coomb's test is done for every Rhesus negative woman at her booking visit, or if she presents in labour unbooked for antenatal care. If indirect Coomb's test is negative at booking, it is repeated at 28 weeks' gestational age. The woman continues her antenatal clinic visit like every other woman if it is negative. If positive, it means that the woman is sensitised, and managed as such. A Rhesus sensitised woman without a history of a previously affected baby is managed with regular antibody titres starting from after 18 weeks' gestational age, and continued every 2 - 4 weeks depending on the antibody titres.

A Rhesus sensitised woman with a history of a previously affected baby is not managed with antibody titres because they do not corelate well with foetal anaemia. They are monitored with regular ultrasound scan for peak flow velocity of the middle cerebral artery. After delivery of the baby, umbilical cord blood is tested to determine the baby's ABO blood group and Rhesus factor before administration of $300 \mu \mathrm{g}$ of antiD immunoglobulin. Anti-D immunoglobulin is given to Rhesus-D negative mothers within 72 hours of delivery of a Rhesus-D positive baby. It is not given if the baby's blood group is $\mathrm{O}$ Rhesus-D negative. Routine antenatal administration of anti-D immunoglobulin to unsensitised women is not practiced in our Centre due its relatively high cost and the low inUniversePG I www.universepg.com cidence of Rhesus negativity and sensitisation in our sub-region. Antenatal anti-D immunoglobulin is administered when there is the possibility of small amount of blood crossing the placenta into the maternal circulation such as during miscarriage, antepartum haemorrhage, external cephalic version, etc. Data were retrieved from the labour ward records, delivery register, theatre records, and patients' folders during the period under review. These records were entered into a pre-designed proforma. These records included age, marital status, level of education, state of residence, occupation, parity, booking status, baby's, patient's and partner's ABO blood group/Rhesus factor, sensitised or unsensitised, sensitising events, gestational age at delivery, mode of delivery, foetomaternal outcome and total number of deliveries during the period under review. Data were analysed using IBM SPSS version 25.0. Results were presented as mean and standard deviation for continuous variables and frequencies or percentages for categorical variables.

\section{RESULTS:}

\section{Sociodemographic characteristics of parturients with Rhesus isoimmunization}

Of the 4,571 pregnant women managed in our Centre in the period under review, 104 women were Rhesus negative, giving an incidence rate of 22.7 in 1,000 pregnancies $(2.27 \%)$. Modal age groups for this population of women were $<25$ years $(30.8 \%)$ and 26-30 years $(30.8 \%)$. Nine in every ten women were married $(92.3 \%)$. With respect to education, $61.5 \%$ had secondary level of education, while $30.8 \%$ had tertiary level of education (Table 1).

Table 1: Sociodemographic characteristics of Rhesus negative women.

\begin{tabular}{|c|c|c|}
\hline Characteristics & $\begin{array}{c}\text { Frequency } \mathbf{N}= \\
\mathbf{1 0 4}\end{array}$ & $\begin{array}{c}\text { Percentage } \\
(\mathbf{\%})\end{array}$ \\
\hline Age Group & \multicolumn{2}{|c|}{} \\
\hline$<25$ years & 32 & 30.8 \\
\hline 26 - 30 years & 32 & 30.8 \\
\hline 31 - 35 years & 24 & 23.1 \\
\hline > 35 years & 16 & 15.4 \\
\hline Mean age \pm SD in years & \multicolumn{2}{|c|}{$30.0 \pm 5.3$} \\
\hline Marital Status & \multicolumn{2}{|}{} \\
\hline Single & 8 & 7.7 \\
\hline Married & 96 & 92.3 \\
\hline Level of education & \multicolumn{2}{|}{} \\
\hline \multicolumn{2}{|l}{} \\
\hline
\end{tabular}




\begin{tabular}{|c|c|c|}
\hline Primary & 8 & 7.7 \\
\hline Secondary & 64 & 61.5 \\
\hline Tertiary & 32 & 30.8 \\
\hline Occupation & & \\
\hline Unemployed & 16 & 15.4 \\
\hline Civil Servant & 24 & 23.1 \\
\hline Trader & 48 & 46.2 \\
\hline Professional & 16 & 15.4 \\
\hline
\end{tabular}

\begin{tabular}{|c|c|c|}
\hline 40 & 8 & 7.7 \\
\hline Mode of Delivery & & \\
\hline Vaginal delivery & 81 & 77.9 \\
\hline $\begin{array}{c}\text { Elective Caesarean } \\
\text { section }\end{array}$ & 23 & 22.1 \\
\hline
\end{tabular}

\section{Obstetric features of Rhesus negative women}

The women were multiparous $(53.8 \%)$, primiparous $(23.1 \%)$ and nulliparous women $(15.4 \%)$. Less than a tenth of them $(7.7 \%)$ were grand-multiparous women (Table 2). Table 2 further reveals that most women were booked (92.3\%) and had vaginal delivery (77. $9 \%)$ at term $(98.0 \%)$.

Table 2: Obstetric features of Rhesus negative women.

\begin{tabular}{|c|c|c|}
\hline Characteristics & Frequency N = 104 & Percentage (\%) \\
\hline Parity & & \\
\hline Nulliparity & 16 & 15.4 \\
\hline Primiparity & 24 & 23.1 \\
\hline Multiparity & 56 & 53.8 \\
\hline Grand-multiparity & 8 & 7.7 \\
\hline Booking status & & \\
\hline Booked & 96 & 92.3 \\
\hline Unbooked & 8 & 7.7 \\
\hline $\begin{array}{c}\text { Gestational Age } \\
\text { at Delivery }\end{array}$ & & \\
\hline 24 & 1 & 1.0 \\
\hline 32 & 1 & 1.0 \\
\hline 37 & 17 & 16.3 \\
\hline 38 & 49 & 47.1 \\
\hline 39 & 12 & 11.5 \\
\hline
\end{tabular}

Blood Groups, Rhesus factor, Anti-D immunoglobulin and Sensitisation

The most common blood group among the women (53.8\%) and their partners $(84.6 \%)$ was the $\mathrm{O}$ blood group (Table 3). While $8(7.7 \%)$ women had blood group $\mathrm{AB}$, none of their partners were blood group AB. Only $2(1.9 \%)$ women in the period under review were sensitised (Table 3). Out of the 104 Rhesus negative women, 81 were unsensitised $(77.9 \%)$, and received anti-D immunoglobulin (Table 3). Two were sensitised, and subsequently lost to follow-up. Thirteen did not receive anti-D immunoglobulin because they had Rhesus negative babies; while the other 8 women were unbooked for antenatal care. However, 3 of the women received antenatal anti-D immunoglobulin due to threatened miscarriage. Thirty-one $(29.8 \%)$ women did not receive post-natal anti-D immunoglobulin due to various reasons (Table 3). Umbilical cord blood was collected from 91 babies for $\mathrm{ABO}$ blood group and Rhesus factor; 13 (14.3\%) were Rhesus negative (Table 3), and the 8 unbooked women declined investigation due to same reasons mentioned above. Samples were not collected from the remaining babies before the placentas were discarded and were an oversight; however, their mothers received anti-D immunoglobulin. Thirty-three (36.3\%) out of the 91 babies that were tested, had ABO incompatibility.

Table 3: Parturients' and Partners' blood groups, Rhesus factor, Anti-D immunoglobulin and Sensitisation status.

\begin{tabular}{|c|c|c|}
\hline Characteristics & Frequency N = 104 & Percentage (\%) \\
\hline Parturients' blood group and Rhesus factor & & \\
\hline O Negative & 56 & 53.8 \\
\hline A Negative & 24 & 23.1 \\
\hline B Negative & 16 & 15.4 \\
\hline AB Negative & 8 & 7.7 \\
\hline Partner's Blood Group & & 84.6 \\
\hline O & 88 & 7.7 \\
\hline A & 8 & 7.7 \\
\hline B & 8 & 92.3 \\
\hline Partner's Rhesus factor & & 7.7 \\
\hline Positive & 96 & \\
\hline
\end{tabular}


Allagoa et al., / European Journal of Medical and Health Sciences, 3(5), 123-131, 2021

\begin{tabular}{|c|c|c|}
\hline Baby's Rhesus factor & N = 91 & \\
\hline Negative & 13 & 14.3 \\
\hline Positive & 78 & 85.7 \\
\hline Sensitized Status & & 98.1 \\
\hline Unsensitised & 102 & 1.9 \\
\hline Sensitised & 2 & 77.9 \\
\hline Received & 81 & 22.1 \\
\hline Post-natal anti-D immunoglobulin (index pregnancy) & 23 & 70.2 \\
\hline Did not receive (Two women were sensitised) & & 29.8 \\
\hline Rost-natal anti-D immunoglobulin (previous pregnancy) & 73 & 10.6 \\
\hline Did not receive & 31 & 4.8 \\
\hline Primigravida & 11 & 14.4 \\
\hline
\end{tabular}

\section{Foetal outcome}

Majority of the babies had a good outcome, though 19 (18.2\%) of them were admitted into the special care baby unit due to neonatal jaundice (14.4\%), birth asphyxia (1.0\%), and prematurity (1.9\%) (Table 4)

Table 4: Foetal outcomes.

\begin{tabular}{l|l|l|} 
Characteristics & Frequency N $=104$ & Percentage (\%)
\end{tabular}

\begin{tabular}{|c|c|c|}
\hline Normal APGAR score & 101 & 97.1 \\
\hline Special care baby unit & 19 & 18.2 \\
\hline Mild Asphyxia & 1 & 1.0 \\
\hline Neonatal jaundice & 15 & 14.4 \\
\hline Prematurity & 1 & 1.0 \\
\hline Perinatal death & 2 & 1.9 \\
\hline
\end{tabular}

*More than one option applies

\section{DISCUSSION:}

In this 5-year review involving an obstetric population of over 4,500 women who presented to this tertiary facility in South-southern Nigeria, we report that $2.27 \%$ of them were $\mathrm{RhD}$-negative (incidence rate of 22.7 per 1000 pregnancies) and is comparable to $2.1 \%$ (Uchenna Eleje et al., 2017) in Anambra State, Southeastern Nigeria and the $2.6 \%$ (Fawole et al., 2001) to $2.9 \%$ (Temitayo and Timothy, 2013) in Ogun State, South-western Nigeria. Our finding was albeit, higher than $0.7 \%$ (Onwuhafua and Adze, 2005) reported in another study in Kaduna, Northern Nigeria. Furthermore, our finding varied considerably from the $4.4 \%$ to 9.5\% reported in studies done predominantly in Southern Nigeria, (Adeyemi and Bello-Ajao, 2016; Idowu et al., 2003; Abasi Bassey et al., 2021; Bolarinwa et al., 2014; Okeke et al., 2012; Otomewo et al.,
2020; Jeremiah, 2005) and also differed from reports of 3.8\% (Mukhtar and Abdulkadir, 2019) in Kano to 6\% (Udomah et al., 2015) in Sokoto by other authors in Northern Nigeria. Similarly, it was lower than the national RhD-negative prevalence of $5.1 \%$ (Anifowoshe et al., 2017) reported by Anifowoshe and colleagues, which reviewed $\mathrm{Rh}$ blood types from 280,514 persons from the six geopolitical zones of Nigeria. Overall, a wide variation seems to exist among the zones in Nigeria and may be reflective of the very diverse ethnocultural groups in the country. This study's finding however suggests a relatively low occurrence of $\mathrm{RhD}$-negative blood group among parturients in our setting, but may also be from its retrospective study design. Our finding also differed from the $10.8 \%$ reported among obstetric populations in other African countries (Ayenew, 2021). Among the RhD-negative parturients in this study, we observed that the group $\mathrm{O}$ was the most predominant among the cohort of women in this review, followed by $\mathrm{A}, \mathrm{B}$ and $\mathrm{AB}$ respectively. Our finding is similar to reports from others authors among obstetric cohorts in various parts of Nigeria (Okeke et al., 2012; Onwuhafua and Adze, 2005; Abasi et al., 2021) and Ethiopia (Ayenew, 2021). But contrast findings from a study in India where group $B$ was the most predominant, followed by $\mathrm{O}, \mathrm{A}$ and $\mathrm{AB}$ respectively (Nagamuthu et al., 2016). We also noted that over four-fifths of partners of the women in our study were blood group $\mathrm{O}$ positive and the ABO blood distribution mirrored what has been reported among the general population in Nigeria (Anifowoshe et al., 2017). It was noted that about two-thirds of our study 
population of RhD-negative mothers were multiparous and contrasts findings from other studies in both Nigeria and Asia where primipara or nullipara accounted for a greater proportion of the study populations reported (Devi et al., 2016; Adewale et al., 2018). However, parity does not affect Rhesus status. Notable in this study was the fact that these were mainly booked mothers who were aware of their RhD-negative status and mostly complied with their antenatal clinic schedules as over two-thirds were observed to have received postnatal anti-D immunoglobulin in their previous pregnancies. It is therefore unsurprising to find an even higher proportion of these women receive post-natal anti-D immunoglobulin in the index pregnancy. Our finding differed from other studies where reports of both post-natal anti-D immunoprophylaxis were lower (Otomewo et al., 2020). Our reported high uptake of immunoprophylaxis among RhD-negative mothers in this study highlights the importance of early detection and hence counselling of affected mothers on the implications of Rhesus negative status on both immediate and future maternal and foetal outcomes. It is worthy of note that this feat was achievable in this facility through collaboration with the pharmacy department such that all booked $\mathrm{RhD}$ negative mothers were enrolled into a 'save-in-bits' plan from day of booking to enable full payment for anti-D immunoglobulin at term or at delivery. Of the remaining few mothers that did not receive postnatal anti-D immunoglobulin for which it was indicated, all were unbooked for antenatal care and declined anti-D immunoglobulin mainly due to financial constraints and ignorance, as most had no adverse outcomes in previous pregnancies. In our setting, mothers access anti-D immunoglobulin by paying out of pocket and the cost varies depending on whether product is either generic or 'branded' and ranges from 38,000 to $\$ 60,000$ (\$ 93 to $\$ 145.8$ per $1,500 \mathrm{IU}$ or $300 \mu \mathrm{g}$ vial), (Central Bank of Nigeria exchange rates: $\$ 411=\$ 1$ ). (CBN, 2021) Other authors have similarly hinged poor rates of post-natal anti-D prophylaxis either in previous or index pregnancies on financial incapability to purchase the immunoglobulin and lack of awareness (Fawole et al., 2001; Uchenna Eleje et al., 2017).

In this study the Rhesus isoimmunisation rate was $1.9 \%$ and occurred in two mothers who were sub- sequently lost to follow-up. Low sensitisation rates have been similarly reported by other authors in Nigeria and range from $0.7 \%$ to $9.1 \%$, predominantly higher rates in unbooked mothers (Adeyemi and BelloAjao, 2016; Onwuhafua and Adze, 2005; Uchenna Eleje et al., 2017; Fawole et al., 2001; Okeke et al., 2012). Our finding corroborates reports from other studies which seem to suggest a relatively low sensitisation rate among Nigerian obstetric population (Otomewo et al., 2020). In addition, no prior sensitisation was also observed even among unimmunised RhD-negative mothers in our study. Our findings raise queries into the role genetics may play as a likely determinant for variations in isoimmunisation status of RhD-negative Nigerian women, and corroborates similar findings by other authors in Nigeria (Abasi Bassey et al., 2021; Otomewo et al., 2020). For sensitisation to occur, combinations of many factors are needed to be present as suggested by Erhabor and colleagues (Erhabor et al., 2021). These include, ABO compatibility of mother and foetus, volume of foetomaternal blood mix and an inverse relation to parity (decreasing sensitisation with increasing pregnancies) (Erhabor et al., 2021).

In this study more of our mothers were multiparous and more than a third (36.3\%) of the babies born to them were $\mathrm{ABO}$ incompatible. In this centre, we do not routinely administer antenatal anti-D immunoglobulin, due to the prohibitive costs if recommended guidelines are to be adhered. Hence, collaborating with local pharmaceuticals and policy makers to actively reduce cost of anti-D immune-globulin is strongly advocated. Notwithstanding, three women received antenatal anti-D immunoglobulin due to threatened miscarriage. In this study, over $90 \%$ of the babies born to RhD-negative mothers were healthy and our findings were consistent with reports from other studies both in and outside Nigeria. Less than a fifth (14.4\%) of the babies had neonatal jaundice and none required exchange blood transfusions. Our findings were likely due to interplay of several factors like; high immunoprophylaxis rate among the mothers, no record of sensitisation and relatively high percentage of maternal and neonatal $\mathrm{ABO}$ incompatibilities among the babies. We however recorded two (1.9\%) perinatal deaths and which were actually mid-trimester 
mis-carriages from the two sensitised mothers who were lost to follow-up afterwards. In these two cases we hypothesise a plausible cause of hydrops fetalis from severe autoimmune mediated haemolytic disease in the foetuses, since during the antenatal period sensitisation had already occurred which could have primarily affected foetal erythropoiesis and cause intrauterine foetal demise.

\section{CONCLUSION:}

Rhesus isoimmunisation is a distressing condition. The Rhesus negative incidence among pregnant women in our study was $2.27 \%$, of which, $1.9 \%$ were sensitised. Timely anti-D immunoglobulin administration after sensitising events and post-delivery is a key in the prevention of Rhesus isoimmunisation. Our study is a single Centre hospital-based study. It may not reflect what is obtainable in other health facilities in our subregion.

\section{ACKNOWLEDGEMENT:}

The authors appreciate the members of staff of the Department of Medical Records of the hospital for their hard work and Dr. Adesina Adedotun Daniel for performing the data analysis.

\section{CONFLICTS OF INTEREST:}

The authors declare that there are no conflicts of interest.

\section{REFERENCES:}

1) Abasi Bassey, E. et al. (2021). Prevalence of Rhesus Negative Status amongst Antenatal Atendees in the University of Uyo Teaching Hospital, Uyo, Nigeria: A 5-Year Review. Clinical Medicine Research, 10(1), 26-30. https://doi.org/10.11648/j.cmr.20211001.15

2) Adewale, F. et al. (2018). Trends of multiple births at federal medical centre bida, Northcentral Nigeria. Tropical Journal of Obstetrics and Gynaecology, 35(1), 68-72. https://doi.org/10.4103/TJOG.TJOG_57_17

3) Adeyemi, A. \& Bello-Ajao, H. (2016). Prevalence of Rhesus D-negative blood type and the challenges of Rhesus D immunoprophylaxis among obstetric population in Ogbomoso, Southwestern Nigeria. Annals of Tropical Medicine and Public Health, 9(1), 12-15.
4) Alakananda et al. (2019). Rhesus Negative Mother and Perinatal Outcome. Scholars International Journal of Obstetrics and Gynecology, 2(11), 284-387. https://www.readcube.com/articles/10.4103\%2F17 55-6783.168722

5) Anifowoshe, A.T. et al. (2017). Gene frequencies of $\mathrm{ABO}$ and $\mathrm{Rh}$ blood groups in Nigeria: A review. Egyptian Journal of Medical Human Genetics, 18(3), 205-210.

https://www.ajol.info/index.php/ejhg/article/view/1 $\underline{59488}$

6) Ayenew, A.A. (2021). Prevalence of rhesus Dnegative blood type and the challenges of rhesus D immunoprophylaxis among obstetric population in Ethiopia: a systematic review and metaanalysis. Maternal Health, Neonatology and Perinatology, 7(1), 8.

https://mhnpjournal.biomedcentral.com/articles/10. 1186/s40748-021-00129-3

7) Bolarinwa, R. et al. (2014). Rhesus incomepatibility amongst child-bearing women in IleIfe, South Western Nigeria. Annals of Tropical Pathology, 5(1), 35-39.

https://www.atpjournal.org/article.asp?issn=22510060 ; year $=2014 ;$ volume $=5 ;$ issue $=1 ;$ spage $=35 ;$ epag $\mathrm{e}=39$; aulast $=$ Bolarinwa; type $=0$

8) CBN, (2021). Central Bank of Nigeria | Exchange Rate. Available at:

https://www.cbn.gov.ng/rates/exchratebycurrency. asp

9) Devi, G.R. et al. (2016). Prevalence of rh negative pregnancy in antenatal women with evaluation of maternal and foetal outcome. Journal of Evidence Based Medicine and Healthcare, 3 (98), 5400-5403.

https://saudijournals.com/media/articles/SIJOG_21 1_284-287.pdf

10) Erhabor, O. et al. (2021). Distribution of Clinically Relevant Blood Group Antigens among Nigerians and the Management of Rhesus D Negative Pregnancies: Implications for Haemolytic Disease of the Foetus and Newborn and Haemolytic Transfusion Reactions. In: Erhabor, O. \& Munshi, A. (eds.) Human Blood Group Systems and Haemoglobinopathies.

https://doi.org/10.5772/intechopen.90372 
11) Erhabor, O. \& Charles, A.T. (2010). Rh isoimmunization in Sub-Saharan Africa indicates need for universal access to anti-RhD immuneglobulin and effective management of D-negative pregnancies. International J. of Women's Health, 2, 429-437.

https://www.ncbi.nlm.nih.gov/pmc/articles/PMC30 24894/

12) Fawole, A.O. et al. (2001). A Review of Rhesus Iso-Immunization in a Nigerian Obstetric Population. Tropical Journal of Obstetrics and Gynaecology, 18(2), 69-72.

https://www.ajol.info/index.php/tjog/article/view/1 $\underline{4433}$

13) Idowu, O.A. et al. (2003). Rhesus negative pregnant women in a traditional birth home in Abeokuta, Nigeria. African Journal of Biotechnology, 2(8), 241-243.

https://www.ajol.info/index.php/ajb/article/view/14 774

14) Jeremiah, Z.A. (2005). An Assessment of the Clinical Utility of Routine Antenatal Screening of Pregnant Women at First Clinic Attendance for Haemoglobin Genotypes, Haematocrit, ABO and $\mathrm{Rh}$ Blood Groups in Port Harcourt, Nigeria. African J. of Reproductive Health, 9(3), 112117.

https://www.ajol.info/index.php/ajrh/article/view/7 $\underline{852}$

15) Moise, K.J. \& Kennedy, M.S. (2021). Management of non-RhD red blood cell alloantibodies during pregnancy: Up To Date. Available at: https://www.uptodate.com/contents/managementof-non-rhd-red-blood-cell-alloantibodies-duringpregnancy

16) Mukhtar, I. \& Abdulkadir, A. (2019). Frequencies of $\mathrm{ABO}$ and Rhesus (D) blood group phenotypes among pregnant women attending antenatal clinic at Murtala Muhammad Specialist Hospital, Kano, Nigeria. Journal of Medicine in the Tropics, 21(1), 31-36.

https://www.jmedtropics.org/article.asp?issn=2276 -7096; year $=2019 ;$ volume $=21$; issue $=1$; spage $=31$; epage $=36$; aulast $=$ Mukhtar; type $=0$

17) Nagamuthu, E. et al. (2016). Prevalence of rhesus negativity among pregnant women.
International Journal of Research in Medical Sciences, 3305-3309.

https://www.msjonline.org/index.php/ijrms/article/ view/1125

18) National Institute for Health and Care Excellence, (2008). Routine antenatal anti-D prophylaxis for women who are rhesus $\mathrm{D}$ negative. Nice Guidelines No. 156. 2008 August; 1-27. Available from: UK (NICE guidance). https://www.nice.org.uk/guidance/ta156/resources/ routine-antenatal-antid-prophylaxis-for-womenwho-are-rhesus-d-negative-pdf-82598318102725

19) Okeke, T.C. et al. (2012). the prevalence of Rhesus negativity among pregnant women in Enugu, Southeast Nigeria. Nigerian Journal of Clinical Practice, 15(4), 400-402.

https://pubmed.ncbi.nlm.nih.gov/23238187/

20) Onwuhafua, P.I. \& Adze, J. (2005). Pregnancy in Rhesus Negative Women in Kaduna, Northern Nigeria. Tropical Journal of Obstetrics and Gynaecology, 21(1), 21-23.

https://www.ajol.info/index.php/tjog/article/view/1 $\underline{4457}$

21) Otomewo, L. et al. (2020). Prevalence of Rhesus $\mathrm{C}$ and D Alloantibodies among Rhesus-Negative Women of Child Bearing Age at a Tertiary Hospital in South-West Nigeria. Nigerian Journal of Clinical Practice, 23(12), 1759-1766.

https://www.njcponline.com/article.asp?issn=1119-

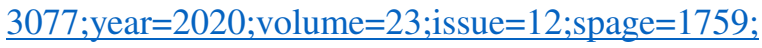
epage $=1766$; aulast $=$ Otomewo

22) Roman, A. (2013). Late Pregnancy Complications: Rh alloimmunization and other blood group incompatibilities. In: Decherney et al. editors. Current Diagnosis and Treatment in Obstetrics and Gynaecology. $11^{\text {th }}$ Ed. New York: McGraw-Hill Companies Inc.

https://accessmedicine.mhmedical.com/content.asp $\underline{x}$ ?bookid $=498 \&$ sectionid $=41008604$

23) Salem, L. \& Singer, K.R. (2017). Rh Incompatibility. Available at:

https://emedicine.medscape.com/article/797150overview

24) Schwarz, H.P. \& Dorner, F. (2003). Karl landsteiner and his major contributions to haematology. British J. of Haematology, 121(4), 556565. https://pubmed.ncbi.nlm.nih.gov/12752096/ 
25) Temitayo, O.I. \& Timothy, S.O. (2013). Frequency Distribution of Hemoglobin Variants and Rhesus Blood Groups among Pregnant Women. Current Research in Medicine, 4(1), 78-81. https://thescipub.com/abstract/10.3844/amjsp.2013 .78 .81

26) Uchenna Eleje, G. et al. (2017) Fetomaternal outcomes of women with Rhesus iso-immunization in a Nigerian tertiary health care in- stitution. Journal of Pregnancy and Neonatal Medicine, 1(01); 21-27.

27) Udomah, F. et al. (2015). Haemoglobin Electrophoretic Patterns, ABO and Rhesus D Blood Groups Distribution among Antenatal Women in Sokoto, Nigeria. Obstetrics and Gynaecology Cases - Reviews, 2(2); 1-4. https://clinmedjournals.org/articles/ogcr/ogcr-2034.pdf

Citation: Allagoa DO, Oriji PC, Briggs DC, Ikoro C, Unachukwu CE, Ubom AE, Atemie G, and Eneni B. (2021). Rhesus negative pregnancy: prevalence and foetomaternal outcomes in a tertiary hospital, South-South Nigeria. Eur. J. Med. Health Sci., 3(5), 123-131. https://doi.org/10.34104/ejmhs.021.012300131 @) () 